\title{
Impact of the 2020 Pandemic on Russian Aviation
}

\author{
G. A. Kalugina ${ }^{a, *}$ and A. V. Ryapukhin ${ }^{a, * *}$ \\ ${ }^{a}$ Moscow Aviation Institute, Moscow, 125080 Russia \\ *e-mail: kalugina@gmail.com \\ **e-mail: anatoliiruapukhin@yandex.ru \\ Received February 8, 2021; revised February 8, 2021; accepted February 8, 2021
}

\begin{abstract}
The 2020 economic crisis brought on by the coronavirus pandemic has affected many sectors of the economy. The markets for air travel and commercial aircraft have been particularly impacted. The present work assesses the current state of aviation and its economic prospects. Global analysis reveals the key economic, political, and social factors determining the outcome of the crisis. Possible remedies are considered, with a particular focus on consolidating Russia's economic position, especially in terms of aviation. The condition of participants in the supply chain is reviewed, and possible pathways for their development are sketched. Recommendations are made regarding the development of Russia's economy, the appropriate use of economic prediction and management, and the best practices in crisis management.
\end{abstract}

Keywords: economic crisis, marketing, aviation, air travel, aircraft manufacture, industry, coronavirus pandemic

DOI: $10.3103 / \mathrm{S} 1068798 X 21070133$

At the beginning of 2020, the World Health organization (WHO) announced the outbreak of a new coronavirus infection, which had developed into the COVID-19 pandemic by March, affecting practically the whole world.

Governments put in place measures to prevent the spread of the virus. Among those were border closures, limits on human mobility, cancelation of mass events, and shuttering of resorts. Besides their public health benefits, these measures had severe economic consequences, in terms of services, entertainment, industry, and air transportation, which is of great strategic importance in Russia and other developed nations. In our analysis of the crisis, we will focus on the largest sector: commercial airlines and aircraft manufacturers.

\section{GLOBAL ECONOMIC SURVEY}

The influence of the COVID-19 pandemic has been different in different countries. The measures needed to support the economy depend on the epidemiological conditions and the economic context in each case. Governments in Europe, Asia, and North America have made unprecedented steps to ameliorate the economic situation, by generous financial support to individuals and businesses. Nevertheless, the International Monetary Fund (IMF) has predicted that, if the spread of the virus is successfully contained in the third quarter of 2020 and adequate support to business continues, the global GDP in 2020 will be $3.0 \%$ less than in 2019 and will grow by only $5.8 \%$ in 2021 [1].
The IMF predicts a more serious downturn than in the 2008 crisis.

\section{IMPACT OF THE PANDEMIC ON AVIATION}

Most companies and international organizations expect a much greater global economic decline from the pandemic than in previous crises. The Archery consulting firm regards the 2020 economic crisis as the most serious in past decades, exceeding those associated with the MERS and SARS epidemics, the 2008 economic bubble, the 9/11 terrorist attacks, the volcanic eruption in Iceland, and the 1990-1991 Persian Gulf war. Archery notes that the current crisis will have the most profound and most lasting effects on aviation.

The International Air Transport Association (IATA) has already reported a $70 \%$ drop in global passenger flights in the second quarter of 2020 relative to the same period of 2019 and expects a decrease in airline revenue by about $\$ 60$ billion [2].

Government mandates have almost totally stopped passenger flights between many countries and regions. The scale of the ban is unprecedented. Scholars and historians note that, even in the Second World War, the limits were less severe.

The situation is similar in Russia. At the end of April 2020, the total passenger load had fallen by a factor of 20. Borders were closed to passenger flights, except in special circumstances. 


\section{MARKET PREDICTIONS}

Predictions of overall economic development and the future of aviation began to appear in the first quarter of 2020. The most authoritative are published by the International Civil Aviation Organization (ICAO) [3] and IATA [2], with monthly updates and shortand long-term (five-year) predictions.

According to the May 2020 forecast, two scenarios of aviation recovery are possible: a V-shaped trend, with recovery almost as fast as the initial decline; and a U-shaped trend, with a greater delay before the upswing begins. The predictions also suggest different growth rates for international flights, which were most affected by the crisis, than for domestic flights.

IATA also provided information about government support for the economy [2]. Governments have provided different subsidies to individuals and businesses, as well as development grants and credits; have injected credit into businesses; and have lightened tax burdens. Such capital infusions in Germany and Italy accounted for around 35\% of GDP; elsewhere in Europe and in the United States, this figure was $10-20 \%$ of GDP. In Russia, this support is no more than $2 \%$ of GDP, although the impact of the virus was no less.

Forecasts for commercial airlines and aircraft manufacturers have been made by various organizations, including Ascend by Cirium [4], Eurocontrol [5], Oliver Wyman [6], and the Teal Group [7].

\section{TRENDS AFFECTING COMMERCIAL AIRLINES AND AIRCRAFT MANUFACTURERS}

To fully understand developments in the air-transport market, we need to study the market participants, their relationships, and their position globally and in Russia in the light of the coronavirus pandemic.

To that end, we now consider each group of participants in turn.

(1) Airlines. The sharp drop in passenger traffic has led to a significant decline in revenue, with some decrease in the variable costs for fuel, staffing, and maintenance. The costs of fleet ownership remain the same. Around $40 \%$ of airplanes are leased globally, as against around $70-80 \%$ in Russia [8]. Since most aircraft are provided by foreign leasing companies, the Russian government's pandemic support will involve keeping up those payments [9]. The increase in unit costs associated with social distancing and other measures will drive up ticket prices and hinder the recovery of traffic volume.

(2) Airports. Like airlines, airports will incur increased costs on account of social distancing. With significant decrease in passenger flows, their revenues will also fall markedly. This will primarily affect major international airports.
(3) Maintenance centers. The revenues of maintenance centers will fall in proportion to traffic volumes. Airline payments may also be delayed. The shutdown will also be an opportunity for airplanes to get rid of old airplanes, which incur higher maintenance costs than new aircraft.

(4) Manufacturers of passenger aircraft. The drop in traffic will greatly affect manufacturers. Traffic loads are not expected to rebound until 2022, and so airlines will have little need to acquire new aircraft for several years. If airlines declare bankruptcy, their aircraft will be released to the resale market, further depressing sales of new planes. That will translate to drop in manufacturing capacity, layoffs closure of some aircraft factories, and stifling of research and development projects. For example, Airbus and Boeing have already reported staff downsizing and reductions in output. One lifeline for manufacturers might be to concentrate resources on promising long-term projects that require little outlay in the immediate future. Without state support, financial results for 2020 and 2021 will be disastrous.

In Russia, the SSJ100 and MC21 development projects are already showing losses and need state support during the crisis. One bright spot is that these are narrow-bodied aircraft designed for regional routes, rather than broad-bodied planes for long-distance routes, which are not expected to recover for some time.

(5) Engine suppliers. These companies are largely dependent on aircraft manufacturers and so face the same challenges.

(6) Suppliers of airplane components, subassemblies, and spare parts. Like engine suppliers, they depend on aircraft manufacturers. Most likely, they will decrease output, diversify their products, search for new markets, and consolidate.

(7) Leasing companies and banks. As a rule, such enterprises make preparations for all possible market crises and minimize their risk, which sits squarely on the lease holder and the aircraft manufacturers. However, banks and leasing companies that hold large order portfolios and own airplane stocks will suffer losses if airlines declare bankruptcy or are temporarily insolvent.

(8) Passengers. Many passengers planning trips for the second quarter of 2020 were forced to cancel. Some airlines reimbursed the ticket price. Others held onto the money, promising to complete the flight at some unspecified time. Prospects for refunds or eventual travel will depend on economic conditions and the condition of the particular airline. The likelihood is very low after the bankruptcy of a small carrier.

(9) Government. As the main regulator of aviation markets, government may determine who bears the risks and suffers the losses by setting policy and providing support during the crisis. Note that, currently, government policy and subsidies in Russia focus on 
many sectors of the economy besides commercial airlines and aircraft manufacturers.

In the current crisis, the dependence of companies on state solutions offers the possibility of modifying market conditions, supporting Russian aircraft manufacturers, and developing long-term strategies, as many countries are doing today. Measures adopted elsewhere include short- and medium-term financial support, tax relief, and equity participation.

Government subsidies, tax relief, and tariffs to support domestic producers sometimes lead to protests from competitors, other countries, and members of international bodies such as the World Trade Organization (WTO). In the present context, however, they may be framed as reasonable responses to the crisis in terms of economic development and public order.

\section{MAJOR FACTORS AFFECTING AVIATION}

As we have seen, authoritative predictions are available regarding the economic impact of the coronavirus pandemic. They differ somewhat in quantitative terms, but the broad conclusions are similar, since all the market surveys are based on similar factors, approaches, and statistical information.

We are most interested in the factors affecting air transport, as follows.

(1) National economic indices.

(1.1) The development of individual sectors and their contribution to the GDP. The pandemic affects individual sectors differently.

(1.2) Inflation.

(1.3) Levels of development of transportation, including aviation; and the economic state of airlines of airports.

(1.4) The contribution of exports of oil and other hydrocarbon fuels to the GDP. Oil prices have dropped during the pandemic.

(1.5) The development of the service sector.

(1.6) The development of medicine and the availability of medical services (paid and unpaid).

(1.7) Demographic data, public health data, material wealth, savings of the population.

(2) Government public-health measures.

(2.1) Quarantines, lockdowns, etc.

(2.2) COVID testing.

(2.3) Medical assistance and humanitarian assistance (financial aid and tax relief).

(3) Business support.

(3.1) Financial support and tax relief.

(3.2) Currency regulation.

(3.3) Credit easing.

(3.4) Targeted support for key sectors, specifically commercial airlines and aircraft manufacturers.

(4) Characteristics of the population.
(4.1) Mobility, including frequency of air travel.

(4.2) Public confidence in the government during the crisis.

(4.3) Education and awareness of the population and compliance with public health regulations.

\section{CONCLUSIONS}

Analysis of the available forecasts reveals the basic factors affecting the economic situation during the coronavirus pandemic and the likely economic performance of commercial airlines and aircraft manufacturers. Relevant considerations are as follows.

(1) Precise economic forecasting is difficult, since major market players will correct their behavior, and predictions will change accordingly.

(2) The spread of the virus is nonuniform. New waves of infection are expected.

(3) Given the gravity of the economic crisis, the resources of various sectors must be focused on tracking and predicting its development, so as to permit comprehensive and systemic appraisal.

(4) In aviation, the most likely scenario is that recovery will begin in the second or third quarter of 2020 and the economy will return to 2019 levels between 2022 and 2024.

(5) The market for air travel is expected to shrink significantly. Consolidation and bankruptcy will reduce the number of market participants. The risks are greatest for international and long-range carriers and wide-bodied long-range aircraft.

(6) Specialists predict surplus capacity, decommissioning of older aircraft, and the availability of many aircraft in secondary markets, at low prices.

(7) All parties in the market are exposed to risks and losses, including passengers. The role of government is to regulate the distribution of losses among the participants.

(8) In the coming months, much will depend on the confidence of passengers regarding their health and economic solvency.

(9) The government will play an essential role in the crisis by adopting effective epidemiological and economic measures (public-health policies, subsidies, tax relief, etc.).

(10) The Russian government has the opportunity to support key sectors and apportion assistance correctly to market participants. In particular, it may switch the focus of commercial aviation to the operation of Russian airplanes, thereby ending the drain of resources to foreign leasing companies and fortifying Russian manufacturers and the economy as a whole.

(11) In summary, the economic crisis associated with the 2020 coronavirus pandemic will be more serious than previous crises. Despite the seriousness of the situation, governments and economists have a real opportunity to correct its consequences, strengthen 
key economic sectors, and refine mechanisms of economic prediction and management.

In the present work, we have made recommendations regarding the development of Russia's economy, the appropriate use of economic prediction and management, and the best practices in crisis management.

\section{REFERENCES}

1. The great lockdown: worst economic downturn since the Great Depression, IMF, 2020. https://blogs.imf. org/2020/04/14/the-great-lockdown-worst-economic-downturn-since-the-great-depression/.

2. COVID-19: Outlook for air travel in the next 5 years, IATA, 2020, https://www.iata.org/en/iata-repository/publications/economic-reports/covid-19-outlookfor-air-travel-in-the-next-5-years/.

3. Effects of novel coronavirus (COVID-19) on civil aviation: economic impact analysis, ICAO, 2020. https:// www.icao.int/sustainability/Documents/COVID-19/ ICAO_Coronavirus_Econ_Impact.pdf.
4. The impact of COVID-19 (coronavirus) on aviation, CIRIUM. https://www.cirium.com/thoughtcloud/visualization-impact-coronavirus-aviation/.

5. COVID-19 impact on the European air traffic network, Eurocontrol, 2020. https://www.eurocontrol.int/covid19/.

6. Wyman, O., An industry in upheaval, 2020. https:// www.oliverwyman.com/our-expertise/insights/2020/ mar/COVID-19-Impact-On-Commercial-AviationMaintenance.html.

7. COVID-19 and civil aviation markets, Teal Group Corporation, 2020. http://tealgroup.com/images/TGCTOC/Covid_Civil_050420.pdf.

8. Kalugina, G.A., Study of the features of the acquisition of civil aircraft by Russian airlines, Amazonia Invest., 2020 , vol. 10 , no. 25 , pp. 443-446. https://amazoniainvestiga.info/index.php/amazonia/article/view/1093/1001.

9. Panteleev, O.K., The winner is the one who breaks the rules of the game, How to save aviation in a crisis. https://www.aviaport.ru/digest/2020/04/01/633091.html.

Translated by B. Gilbert 